\title{
SEROLOGIC SURVEY ON HANTAVIRUS IN BLOOD DONORS FROM THE STATE OF SANTA CATARINA, BRAZIL
}

Caio Maurício Mendes de CORDOVA(1) \& Luiz Tadeu Moraes FIGUEIREDO(2)

\begin{abstract}
SUMMARY
Emergent diseases such as Hantavirus Cardio-pulmonary Syndrome (HCPS) are able to create a significant impact on human populations due to their seriousness and high fatality rate. Santa Catarina, located in the South of Brazil, is the leading state for HCPS with 267 reported cases from 1999 to 2011. We present here a serological survey on hantavirus in blood donors from different cities of the state of Santa Catarina, with an IgG-ELISA using a recombinant nucleocapsid protein from Araraquara hantavirus as an antigen. In total, 314 donors from blood banks participated in the study, geographically covering the whole state. Among these, 14 individuals (4.4\%) had antibodies to hantavirus: four of 50 (8\% positivity) from Blumenau, four of $52(7.6 \%)$ from Joinville, three of $50(6 \%)$ from Florianópolis, two of 50 (4\%) from Chapecó and one of $35(2.8 \%)$ from Joaçaba. It is possible that hantaviruses are circulating across almost the whole state, with important epidemiological implications. Considering that the seropositive blood donors are healthy individuals, it is possible that hantaviruses may be causing unrecognized infections, which are either asymptomatic or clinically nonspecific, in addition to HCPS. It is also possible that more than one hantavirus type could be circulating in this region, causing mostly benign infections.
\end{abstract}

KEYWORDS: Hantavirus; Seroprevalence; Blood Donors; Hantavirus Cardio-pulmonary Syndrome.

\section{INTRODUCTION}

Emergent diseases that are commonly caused by zoonotic microbes, such as Hantavirus Cardio-Pulmonary Syndrome (HCPS), cause a significant impact on human populations due to their seriousness and high case fatality rates. Hantaviruses are 100 to $120 \mathrm{~nm}$ in diameter tri-segmented RNA viruses of the Bunyaviridae family. The large (L) RNA segment codes for a RNA polymerase, the medium (M) segment encodes the glycoproteins of viral surface (Gn and Gc), and the small segment $(\mathrm{S})$ codes for the nucleocapsid $(\mathrm{N})$ protein, which is an important viral antigen and induces antibody production after infection ${ }^{3}$. Small mammals, especially rodents, are the natural reservoirs of hantavirus. The transmission of these viruses to man occurs by the inhalation of contaminated aerosols containing excreta of infected rodents. In the Americas, hantaviruses are the cause of HCPS, which has been recognized since $1993^{5}$. In Brazil, about 1600 HCPS cases were reported from 1993 to 2013 with a $40 \%$ case fatality rate (Source: SVC/MS). Five hantaviruses are known to cause HCPS in Brazil: Anajatuba, Araraquara (ARAV), Castelo dos Sonhos (CSV), Juquitiba (JUQV), and Laguna Negra-like virus ${ }^{3}$. Some factors could be highlighted as contributors to the emergence of hantaviruses, including ecological degradation with deforestation for poorly planned urban expansion, intensive agriculture and cattle raising.
In recent years, a recombinant $\mathrm{N}$ protein of ARAV was developed, which has been used as an antigen in an ELISA for the diagnosis of hantavirus infections ${ }^{4}$. This ELISA is considered an important weapon for serologic surveillance of hantavirus infections in humans and rodents in Brazil and has been used in many epidemiological studies.

Santa Catarina, located in the South of Brazil, is the leading state on HCPS reported cases (Source: SVC/MS). However, the prevalence and other factors related to hantavirus infection and HCPS are not well known in the state. We present here a serologic survey of hantavirus in blood donors from different cities of the state of Santa Catarina, by using an IgG-ELISA with the $\mathrm{N}$ recombinant protein of ARAV.

\section{MATERIAL AND METHODS}

Participants and serum samples: In total, 317 blood donors from both genders (101 men and 216 women), from ages of 18 to 68 years participated in this serological survey. From February through March 2012, these participants donated blood and those that signed a consent form were enrolled in the study. In order to geographically represent the whole state of Santa Catarina, 40 to 50 participants from each of the blood banks in the state's larger cities were included in the study: Blumenau city in the Itajaí Valley; Joinville, in the north of the state; Florianópolis city,

(1) Universidade de Blumenau-FURB, Depto. de Ciências Farmacêuticas, Blumenau, SC, Brazil.

(2) Universidade de São Paulo-USP-RP, Faculdade de Medicina, Centro de Pesquisa em Virologia. Ribeirão Preto, SP, Brazil.

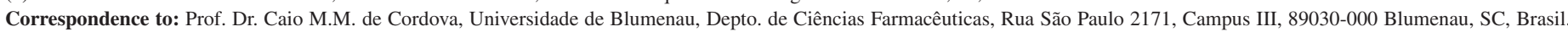
Tel: +55 473321 7318. E-mail: cmcordova@ furb.br 
in the eastern coast; Criciúma city, in the south of the state; Lages city, in the central mountains plateau; and Chapecó city and Joaçaba city, in the west of the state. A $5 \mathrm{~mL}$ blood sample was collected in Vacutainer ${ }^{\mathrm{TM}}$ (Becton Dickinson, Franklin Lakes, NJ, USA) from each participant by an officer of the blood bank, together with samples used for routine serologic tests. The blood was centrifuged at 3,000 rpm for five min; the serum was separated, carried to the laboratory on ice and stored at $-20{ }^{\circ} \mathrm{C}$ until use. This Research Project was approved by the Ethics Committee for Human Research of the Regional University of Blumenau (Protocol $\mathrm{n}^{\circ}$ 155/10), in accordance with the Helsinki Declaration of 1975 as revised in 1983 and the International Ethical Guidelines for Biomedical Research Involving Human Subjects (CIOMS/OMS 1982 \& 1993).

IgG-ELISA for hantavirus: The serum samples were tested in duplicate by an anti-hantavirus IgG-ELISA using the $\mathrm{N}$ recombinant protein of ARAV as antigen. Tests were performed as previously described $^{4}$. Briefly, polystyrene microtiter plates (polystyrene high biding, Corning) were coated overnight in a wet chamber at $4{ }^{\circ} \mathrm{C}$ with $2 \mu \mathrm{g} / \mathrm{mL}$ of ARAV N protein, or control antigen. All incubations were conducted at $37^{\circ} \mathrm{C}$ for one hour and plates were washed six times with a wash buffer (phosphate-buffered saline [PBS]-0.1\% Tween 20) between each step. Firstly, $150 \mu \mathrm{L}$ of a blocking solution containing $10 \%$ skimmed milk in powder in [PBS]-0.1\% Tween 20 was added to the wells. All serum samples were diluted 1:100 in dilution buffer (5\% skimmed milk powder in PBS-Tween-20), as were the positive and the negative control sera, and $50 \mu \mathrm{L}$ was added to the antigen-coated wells. Peroxidase-labeled affinity-purified goat anti-human IgG Fc antibody (50 $\mu \mathrm{L} /$ well) was added and specific antibody binding was detected by the addition of 2,2'-azino-bis(3-ethylbenzthiazoline-6-sulfonic acid) (ABTS) substrate (100 $\mu \mathrm{L} /$ well), with the absorbance measured at $405 \mathrm{~nm}$. Values were expressed as the optical density (OD) obtained with ARAV $\mathrm{N}$ antigen minus the OD values for the control antigens. The cut-off value of the test was determined by the mean plus three standard deviations of the ODs obtained for at least four negative-control serum samples, plus three standard deviations of the mean.

\section{RESULTS AND DISCUSSION}

This serologic survey of the hantavirus included 314 participants from blood banks geographically covering the whole state of Santa Catarina (Fig. 1). Of these, 14 individuals (4.4\%) had antibodies to hantavirus: four of 50 ( $8 \%$ positivity) from Blumenau city, four of 52 (7.6\%) from Joinville city, three of 50 (6\%) from Florianópolis city, two of 50 (4\%) from Chapecó city and one of 35 (2.8\%) from Joaçaba city. No seropositive results were observed among the 42 participants of Criciúma city or 35 participants from Lages city.

The levels of antibody to hantavirus in blood donors in any state could provide information on the circulation of these viruses in the entire state, including geographical areas where HCPS has not been reported.

Hantavirus infections causing HCPS are well known in the state of Santa Catarina, as 267 confirmed cases were reported from 1999 through December 2011. Curiously, only a few HCPS cases have been reported on the eastern coast in the state Capital Florianópolis, and in the north-eastern region of Joinville ${ }^{2}$. In the present study, more than $50 \%$ of individuals that were seropositive for hantavirus were from these regions. Antibodies to hantavirus were not detected in participants from the South

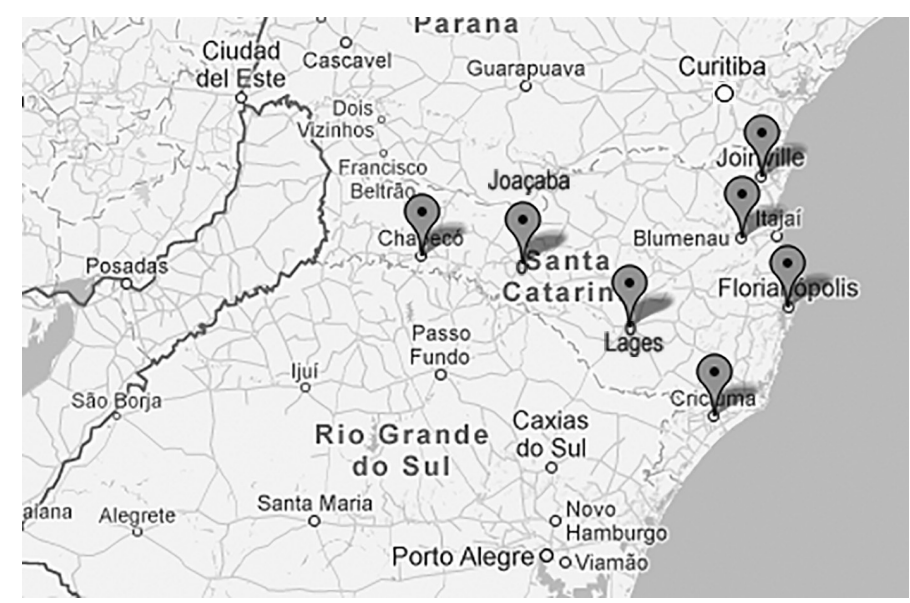

Fig. 1 - Map of the South of Brazil showing the city location of blood banks of the state of Santa Catarina that provided participants for the Hantavirus serological survey. Source: http://maps.google.com/

of Santa Catarina (Criciúma city). However, a study in a rural population next to Criciúma city showed a $2.3 \%$ seroprevalence to hantavirus and all seropositive individuals referred a previous severe pneumonia that could have been $\mathrm{HCPS}^{6}$.

This study shows that $4.4 \%$ of blood donors are infected by hantavirus in most of the Santa Catarina territory. Considering that blood donors are commonly local inhabitants, it is possible that hantaviruses are circulating across practically all of the state. Of note, a study including 340 individuals inhabiting two cities in the western border of the state of Santa Catarina with Argentina, found 3.5\% of individuals to be seropositive for hantavirus ${ }^{7}$. It might be worth noting that hantavirus infection is usually acquired by contact with wild rodents, often in the rural areas, and not in the urban environment. Blood Banks as the ones evaluated in the present study usually receive donors from the whole region they serve, or even from abroad. Additional studies evaluating the precise origin of the seropositive donors might be of interest to determine the possible site of origin of hantavirus exposure.

Considering that the seropositive blood donors are healthy individuals, it is possible that hantaviruses may be causing unrecognized infections, which are either asymptomatic or clinically nonspecific, in addition to HCPS. It is also possible that more than one hantavirus type could be circulating in this region, causing mostly benign infections. Once immune activation has been associated with HCPS pathogenesis, it is possible that some polymorphisms in genes involved in immune response may affect the development of $\mathrm{HCPS}^{1}$. Further studies are necessary in order to explain unrecognized infections by hantaviruses.

\section{RESUMO}

\section{Inquérito sorológico para hantavírus em doadores de sangue no Estado de Santa Catarina, Brasil}

Doenças emergentes como a Síndrome Cárdio-Pulmonar por Hantavírus (SCPH) são capazes de promover um grande impacto nas populações humanas devido a sua severidade e alta letalidade. Santa Catarina, localizada ao Sul do Brasil, é o estado com o maior número 
de relatos de SCPH, com 267 casos desde 1999 a 2011. Apresentamos aqui um inquérito sorológico para hantavírus em doadores de sangue de diferentes cidades do Estado de Santa Catarina, usando um teste IgG-ELISA com proteína recombinante de nucleocapsídeo do hantavírus Araraquara como antígeno. No total, 314 doadores de banco de sangue participaram do estudo, cobrindo geograficamente todo o Estado. Dentre estes, 14 indivíduos $(4,4 \%)$ apresentaram anticorpos para hantavírus: quatro de 50 ( $8 \%$ de positividade) provenientes de Blumenau, quatro de $52(7,6 \%)$ de Joinville, três de 50 (6\%) de Florianópolis, dois de 50 (4\%) de Chapecó e um de 35 (2,8\%) de Joaçaba. É possível que hantavírus estejam circulando praticamente em todo o Estado, com implicações epidemiológicas importantes. Considerando que os doadores de sangue soropositivos são indivíduos saudáveis, é possível que hantavírus possam estar causando infecções não diagnosticadas, sejam elas assintomáticas ou clinicamente inespecíficas, além da SCPH. É possível ainda que mais de um tipo de hantavírus possa estar circulando na região, causando infecções mais benignas.

\section{ACKNOWLEDGEMENTS}

The authors acknowledge all blood donors that kindly agree to participate of this study. The authors also acknowledge the directors and officers of the blood bank of the state of Santa Catarina (HEMOSC) that participated in the study.

\section{AUTHORS CONTRIBUTIONS}

Cordova CMM was responsible for sample collection, experimental procedures and writing the manuscript, and collaborated in study design; Figueiredo LTM was responsible for the study design, and collaborated in the experimental procedures and writing the manuscript.

\section{FINANCIAL SUPPORT}

Ministry of Health, Brazil; Ministry of Science and Technology; State
Secretary of Health of Santa Catarina; Fundação de Amparo à Pesquisa e Inovação do Estado de Santa Catarina; University of Blumenau; MS/ CNPq/FAPESC/SES PPSUS 003/2010 research grant $\mathrm{n}^{\circ}$ 3.747-2011-8.

\section{REFERENCES}

1. Borges AA, Donadi EA, Campos GM, Moreli ML, de Sousa RL, Saggioro FP, et al. Association of $-308 \mathrm{G} / \mathrm{A}$ polymorphism of tumor necrosis factor- $\alpha$ gene promoter with susceptibility to development of hantavirus cardiopulmonary syndrome in the Ribeirão Preto region, Brazil. Arch Virol. 2010;155:971-5.

2. DIVE-SES-SC. Diretoria de Vigilância Epidemiológica, Secretaria de Estado da Saúde de Santa Catarina 2012. A hantavirose no Estado de Santa Catarina, 20002011. Florianópolis: Secretaria de Estado da Saúde. Sistema Único de Saúde. Superintendência de Vigilância em Saúde. Diretoria de Vigilância Epidemiológica. [cited 2013 Jan 28 ]. Available from: http://www.dive.sc.gov.br/conteudos/zoonoses/ RoedoresAves/Hantavirose/Hantavirose_no_estado_SC.pdf

3. Figueiredo GG, Borges AA, Campos GM, Machado AM, Saggioro FP, Sabino Júnior GS, et al. Diagnosis of hantavirus infection in humans and rodents in Ribeirão Preto, State of São Paulo, Brazil. Rev Soc Bras Med Trop. 2010;43:348-54.

4. Figueiredo LT, Moreli ML, Borges AA, de Figueiredo GG, Badra SJ, Bisord I, et al. Evaluation of an enzyme-linked immunosorbent assay based on Araraquara virus recombinant nucleocapsid protein. Am J Trop Med Hyg. 2009;81:273-6.

5. Nichol ST, Spiropoulou CF, Morzunov S, Rollin PE, Ksiazek TG, Feldmann H, et al. Genetic identification of a hantavirus associated with an outbreak of acute respiratory illness. Science. 1993;262(5135):914-7.

6. Pereira GW, Teixeira AM, Souza MS, Braga AD, Santos Junior GS, Figueiredo GG, et al. Prevalence of serum antibodies to hantavirus in a rural population from the southern state of Santa Catarina, Brazil. Rev Soc Bras Med Trop. 2012;45:117-9.

7. Souza WM, Machado AM, Disner GR, Boff E, Machado ARSR, Pádua M, et al. Antibody levels to hantavirus in inhabitants of western Santa Catarina State, Brazil. Rev Inst Med Trop Sao Paulo. 2012;54:193-6.

Received: 27 March 2013

Accepted: 8 January 2014 